\title{
CONCOMITANT EXTRACTION PROCESS OF NIOBIUM AT THE TITANIUM TETRACHLORIDE PRODUCTION
}

\author{
T.K. Sarsembekov ${ }^{1}$, T.B. Yanko ${ }^{2}$, S.A. Sidorenko ${ }^{2}$, M.M. Pylypenko ${ }^{3}$ \\ ${ }^{1}$ JSC “Ust-Kamenogorsk Titanium and Magnesium Plant”, Ust-Kamenogorsk, Kazakhstan; \\ ${ }^{2}$ PJSC Titanium Institute, Zaporizhzhya, Ukraine; \\ ${ }^{3}$ National Science Center "Kharkov Institute of Physics and Technology", \\ Kharkiv, Ukraine \\ E-mail:Titanlab3@ukr.net
}

Development of the fundamentals of a technology for producing niobium by the concomitant extraction in the process of production of titanium tetrachloride from titanium raw materials. The paper provides data on the amount of niobium contained in the feedstock to produce titanium tetrachloride, the distribution of niobium during processing by products and waste. The forms of phase transformations and transitions of niobium during processing are considered. Schemes for processing niobium-containing chloride materials and technologies for their further application for producing alloys for nuclear power are proposed.

\section{INTRODUCTION}

\section{PROPERTIES AND NIOBIUM MINERALS}

Niobium is a light gray ductile metal, its density is $8.58 \mathrm{~g} / \mathrm{cm}^{3}$, its melting point is $2469{ }^{\circ} \mathrm{C}$, and its boiling point is $4842{ }^{\circ} \mathrm{C}$ [1]. Niobium has one stable ${ }^{93} \mathrm{Nb}$ isotope, several radioactive isotopes are artificially produced.

Among all refractory metals, niobium has the highest transition temperature to the state of superconductivity $9.17 \mathrm{~K}$. The thermal conductivity and heat capacity of niobium increase with increasing temperature. The temperature coefficient of linear expansion of niobium with increasing temperature increases in the same way as the electrical resistivity. The above properties depend largely on the purity degree of the metal [2].

Niobium is a rare-earth element; its content in the earth's crust is $2 \cdot 10^{-3} \%$ of the mass $[1,3]$. The main minerals of niobium are columbite, laporite, pyrochlore, perovskite, ilmeno-rutile. Fig. 1 shows the dynamics of the production of the main niobium raw materials in the period 2001-2014.

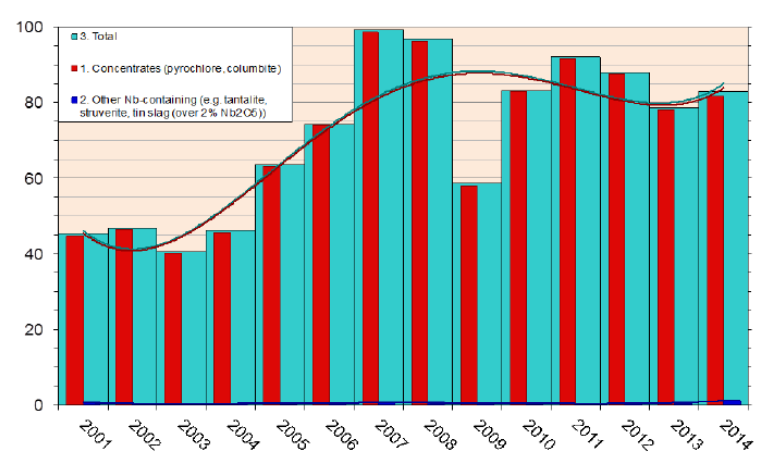

Fig. 1. Extraction of basic niobium raw materials in 2001-2014

Fig. 2 shows the dynamics of production of nonbasic niobium raw materials in the period 2001-2014.

An important feature of niobium is a great affinity to titanium, and the ability to heterovalent isomorphism with him. This causes the formation of titanium- niobium numerous minerals as well as the occurrence of niobium impurity in the titanium minerals (rutile, perovskite, ilmenite, and others) $[1,4]$.

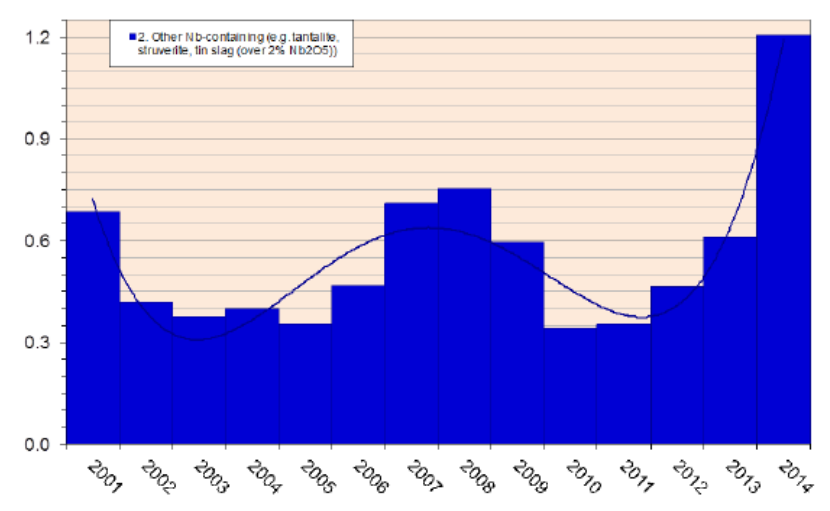

Fig. 2. Extraction of non-basic niobium raw materials in 2001-2014

\section{APPLICATION OF NIOBIUM}

A successful combination of niobium properties: strength, high heat resistance, corrosion resistance, refractoriness, low temperature range of the transition from plastic to brittle state allow it to be widely used as a high-temperature structural material.

Niobium is used in many key industries, engineering: in the production of steels and alloys, electronics, chemical engineering and nuclear energy (Fig. 3).

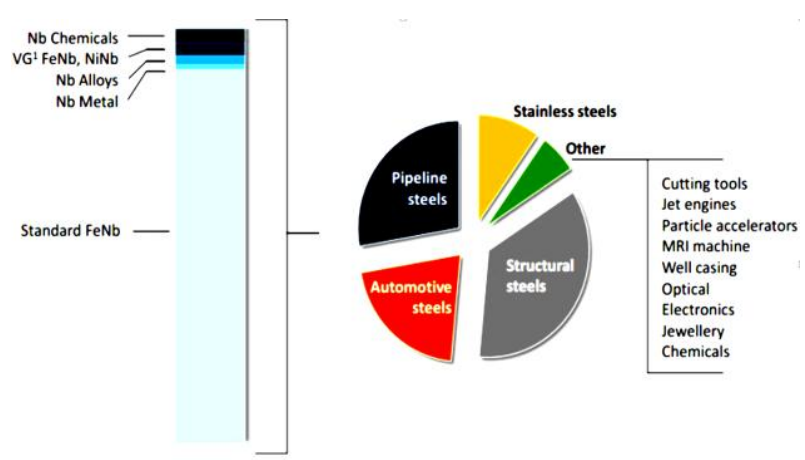

Fig. 3. Consumption of niobium [5] 
The global steel industry accounted for about $90 \%$ of global niobium consumption. Niobium is not used in all HSLA and stainless steels; however, in the grades in which it is used, HSLA steels contain about $0.05 \%$ niobium by weight, and stainless steels from 0.04 to $0.08 \%$. HSLA steels have become a leading consumer of ferroniobium; structural steel accounted for $45 \%$ of global ferroniobium consumption; automotive steel, $23 \%$; steel line, 16\%; and stainless steel, 6\%. The world's leading producers of ferroniobium were CBMM (Brazil), Mineração Catalão de Goias (Brazil) and IAMGOLD Corp. (Canada), which together accounted for most of the world production of niobium and sold their products in the form of ferroniobium (Fig. 4). World supplies of ferroniobium, measured in the contained niobium, amounted to $53.500 \mathrm{t}$ in 2012, an increase from $52.200 \mathrm{t}$ in 2011 [6].

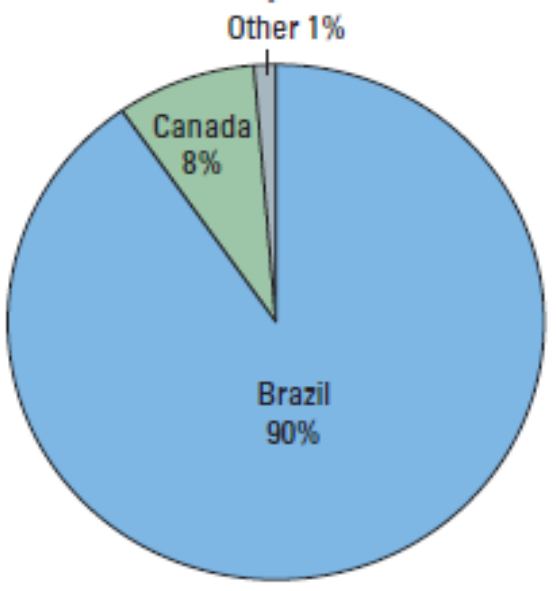

Fig. 4. Countries producing niobium

Ferroniobium and nickel-niobium are used in super alloys used in the aerospace industry, particularly in engines of commercial aircraft, as well as in land-based gas turbines for the production of electricity and in corrosion-resistant alloys. Titanium and zirconiumniobium alloys are used in aeronautics, superconductors and nuclear energy. Niobium-based chemicals are used in many fields, such as catalysts and functional ceramics.

However, widespread use of niobium in certain branches of industry and technology is constrained by its scarcity and high cost. Therefore, the questions of recycling niobium-containing materials remain relevant $[7,8]$.

Niobium can be recovered as a by-product of tin production wastes or recovered from sludge from the processing of carbide tools or from scrap alloyed and unalloyed metal and scrap from industrial alloys and superalloys.

Regarding products that have expired, the niobium is contained in $[9,10]$.

Waste electrical and electronic equipment (WEEE). It has been estimated that a computer may contain $0.0002 \%$ niobium. The amount of niobium extracted from the assembled IT and telecommunication equipment can reach $1.2 \mathrm{t}$, and the niobium content in PCBs is about $36 \mathrm{~g} / \mathrm{t}$.
Expired Vehicles. The niobium content in the ELV can be estimated due to the niobium content in stainless steels, which is in the range of $0.04 \ldots 0.08 \%$.

The potential sources for the extraction of niobium are mainly steel, but the niobium content is low $(<0.5$ wt. $\%)$.

One of the directions for obtaining niobium is its associated extraction from products of chlorine processing of titanium-containing materials.

For example, in titanium slag, niobium is initially contained in the form of $\mathrm{Nb}_{2} \mathrm{O}_{5}$ oxide. Based on the average content of $\mathrm{Nb}_{2} \mathrm{O}_{5}$ in titanium slag $-0.12 \%$, the amount of niobium metal in it can be estimated. Given the molecular weights of niobium and oxygen, the content of niobium metal in titanium slag will be $0.08 \%$, the amount of niobium metal in 1 ton of titanium slag will be $0.81 \mathrm{~kg}$. This means that in the course of processing $20.000 \mathrm{t}$ of titanium slag per year, $16.2 \mathrm{t}$ of niobium are lost with waste. Studying the distribution and creating technology for the extraction of niobium in the production of titanium tetrachloride will increase the complexity of processing titanium-containing raw materials, as well as create an additional source of production of scarce metal.

\section{EXPERIMENTAL}

Since ilmenite belongs to complex oxides [1], niobium is contained in it in the form of $\mathrm{Nb}_{2} \mathrm{O}_{5}$. The content of $\mathrm{Nb}_{2} \mathrm{O}_{5}$ in ilmenite ranges from $0.26 \ldots 1.55 \%$ [2]. During ore-thermal reduction smelting of ilmenite concentrate, $\mathrm{Nb}_{2} \mathrm{O}_{5}$ is almost completely converted to titanium slag, since niobium is not reduced by carbon. $\Delta \mathrm{G}$ of the reduction reaction of $\mathrm{Nb}_{2} \mathrm{O}_{5}$ with carbon at a temperature of $1500{ }^{\circ} \mathrm{C}$ is $1564.6 \mathrm{~kJ}$. The environment for the chlorination of titanium slag is a molten alkali metal salt at a temperature of $700 \ldots 820^{\circ} \mathrm{C}$.

During chlorination of titanium slag in the melt at temperatures of $700 \ldots 820{ }^{\circ} \mathrm{C}$ in the presence of carbon relatively to $\mathrm{Nb}_{2} \mathrm{O}_{5}$, thermodynamically probable course of the following reactions:

$$
\begin{aligned}
2 \mathrm{Nb}_{2} \mathrm{O}_{5}+6 \mathrm{Cl}_{2}+3 \mathrm{C}=4 \mathrm{NbOCl}_{3}+3 \mathrm{CO}_{2} \\
(\Delta \mathrm{G}=-594,8 \ldots-563,6 \mathrm{~kJ}) \\
2 \mathrm{Nb}_{2} \mathrm{O}_{5}+10 \mathrm{Cl}_{2}+5 \mathrm{C}=4 \mathrm{NbCl}_{5}+5 \mathrm{CO}_{2} \\
(\Delta \mathrm{G}=-987.5 \ldots-974.9 \mathrm{~kJ}) \\
2 \mathrm{Nb}_{2} \mathrm{O}_{5}+6 \mathrm{Cl}_{2}+5 \mathrm{C}=4 \mathrm{NbCl}_{3}+5 \mathrm{CO}_{2} \\
(\Delta \mathrm{G}=-527.2 \ldots-534.2 \mathrm{~kJ})
\end{aligned}
$$

Chlorination of niobium pentoxide in the presence of carbon produces $\mathrm{NbOCl}_{3}$ mixed with $\mathrm{NbCl}_{5}$. This process can be described by the reaction:

$$
\mathrm{Nb}_{2} \mathrm{O}_{5}+4 \mathrm{Cl}_{2}+2 \mathrm{C}=\mathrm{NbOCl}_{3}+\mathrm{NbCl}_{5}+2 \mathrm{CO}_{2}
$$$$
(\Delta \mathrm{G}=-395.8 \ldots-384.6 \mathrm{~kJ}) \text {. }
$$

Those, oxytrichloride and niobium pentachloride are transferred into the vapor-gas mixture. The sublimation temperature of $\mathrm{NbOCl}_{3}$ is $400{ }^{\circ} \mathrm{C}$, the boiling point of $\mathrm{NbCl}_{5}$ is $248.3^{\circ} \mathrm{C}$ [11].

It was experimentally established that the chlorinator melt assimilates a certain amount of niobium, the value of which is $0.13 \ldots 0.26 \mathrm{~kg}$ of $\mathrm{NbOCl}_{3}$ per $1 \mathrm{t}$ of technical titanium tetrachloride and depends on the chemical composition of the melt. Insignificant assimilation of niobium in the chlorinator is explained by low thermal stability of complexes of niobium oxytrichloride with alkali metal chlorides, as well as its 
displacement from complexes by magnesium, iron, and aluminum chlorides.

The temperature in the dust chamber is maintained within $600 \ldots 500{ }^{\circ} \mathrm{C}$, thus, the compounds of oxytrichloride and niobium pentachloride do not accumulate in the sublimates of the dust chamber.

Next, the niobium compounds in the vapor-gas mixture fall into a dust precipitation chamber with a salt bath (DSS), wherein the temperature is maintained within a $350 \ldots 300{ }^{\circ} \mathrm{C} . \mathrm{NbOCl}_{3}$ in this temperature range is sublimated and falls into the melt DSS. The low degree of niobium trapping into the salt scrubber is due to the low partial pressure of niobium oxychloride at a temperature of the steam-gas mixture at the outlet of the apparatus.

The $\mathrm{Nb}$ content in the DSS melt, in terms of $\mathrm{Nb}_{2} \mathrm{O}_{5}$, is $0.05 \%$. The content of aluminum trichloride in the DSS melt reaches $40 \%$. At operating temperatures in DSS possible reaction [9]:

$$
\begin{gathered}
\mathrm{NbOCl}_{3}+\mathrm{AlCl}_{3}=\mathrm{NbCl}_{5}+\mathrm{AlOCl} \\
(\Delta \mathrm{G}=-3.5 \ldots-3.2 \mathrm{~kJ}) .
\end{gathered}
$$

The direct proportional dependence of the niobium content in the slurry of the irrigation scrubber on the $\mathrm{AlCl}_{3}$ content in the DSS melt is confirmed by practical observations. When topping the sludge-electrolyte mixture into the DSS melt, i.e. with a decrease in $\mathrm{AlCl}_{3}$ content, a decrease in the $\mathrm{Nb}$ content in the slurry is observed.

The resulting mixture of $\mathrm{NbOCl}_{3}$ and $\mathrm{NbCl}_{5}$ together with the vapor-gas mixture enters the irrigation scrubber. In the irrigation scrubber, the temperature is maintained no more than $125^{\circ} \mathrm{C}$. The trapping coefficient of niobium in the irrigation scrubber is $98.5 \%$, so the bulk niobium is condensed with circulating slurry. Circulation of pulp along the contour (irrigation scrubber - chlorinator - irrigation scrubber) contributes to the accumulation of niobium oxychloride in solid suspensions of the slurry in the form of a yellow solid impurity [12]. The solids content in the pulp reaches $100 \mathrm{~g} / \mathrm{l}$, the $\mathrm{Nb}$ content in terms of $\mathrm{Nb}_{2} \mathrm{O}_{5}$ reaches more than $20 \%$.

In deriving mixture pentaoxychloride and niobium should consider the possibility of further applications. Most methods for producing niobium metal are not related to its reduction from the chloride form, and although hydrogen reduction involves the production of compact niobium rods, it is still a promising technology [11]. Therefore, it is most preferable to consider metallothermal reduction with magnesium, since this technology has been sufficiently developed in the production of titanium and zirconium. Most certified zirconium alloys for nuclear power include niobium in the form of an alloying component (Table).

Chemical composition of typical nuclear zirconium alloys

\begin{tabular}{|c|c|c|c|c|c|c|c|}
\hline \multirow{2}{*}{ Alloy } & \multirow{2}{*}{$\begin{array}{c}\text { Type of } \\
\text { reactor }\end{array}$} & \multicolumn{7}{|c|}{ Content,\% wt. } \\
\cline { 3 - 8 } Zircaloy-2 & $\begin{array}{c}\text { BWR, } \\
\text { CANDU }\end{array}$ & $1,2-1,7$ & $0,07-0,20$ & $0,03-0,08$ & - & $0,05-0,15$ & 0,125 \\
\hline Zircaloy-4 & $\begin{array}{c}\text { BWR, PWR, } \\
\text { CANDU }\end{array}$ & $1,2-1,7$ & $0,18-0,24$ & - & - & $0,07-0,13$ & 0,125 \\
\hline M5 & PWR & - & $<0,05$ & - & $0,8-1,2$ & - & 0,125 \\
\hline Zr-2.5Nb & $\begin{array}{c}\text { CANDU, } \\
\text { RBMK }\end{array}$ & - & - & - & $2,4-2,8$ & - & 0,125 \\
\hline ZIRLO & PWR & - & $0,09-0,10$ & - & $1,0-1,2$ & - & 0,125 \\
\hline E110 & WWER & - & $<0,05$ & - & $0,9-1,1$ & - & $<0,099$ \\
\hline E125 & WWER & - & $<0,05$ & - & $2,4-2,7$ & - & $<0,099$ \\
\hline E635 & WWER & $1,1-1,3$ & $0,3-0,4$ & - & $0,9-1,1$ & - & $0,05-0,12$ \\
\hline
\end{tabular}

Zirconium-niobium alloys are extensively used as materials for fuel claddings, pressure tubes in CANDU reactors and to a certain extent for other structural components such as fuel channels, in various types of operating nuclear reactors. The properties of zirconium alloys depend on the chemical composition and the heat treatment of the alloy for each type of reactor.

Niobium in $\mathrm{Zr}-\mathrm{Nb}$ alloys increases the stability of the $\beta$-phase, which provides increased corrosion and mechanical resistance of the structural material of the fuel elements of the cladding. Based on this, the authors consider that one of the most promising areas is a possibility of using integrated technology of zirconiumniobium alloys producing for nuclear power engineering method for magnesium thermal reduction.

Most of the known methods of alloying zirconium consist in the technological step of introducing alloying elements in the form of ligatures into the zirconium batch [13]. This operation, along with technological difficulties, does not provide a complete and uniform distribution of alloying elements in the resulting semifinished products, which necessitates an increase in the number of technological operations to obtain finished products - zirconium alloys [14]. In general, the technology for producing a structural product from zirconium alloys includes in some cases more than 50 operations. Reducing the number of operations or eliminating some technological steps in general, without changing the quality indicators of alloys and products, can significantly reduce the cost of production. One of the episodes, which is decisive in the component of the cost of manufacturing zirconium alloys, is the stage of remelting zirconium with alloying elements to obtain a predetermined chemical composition. The crushed 
sponge zirconium is mixed with the crushed ligatures, which are often more expensive than the main material, form the batch into briquettes or press blocks, depending on the method of further processing, and remelt. For one melting, it is not possible to achieve a uniform distribution of alloying elements in the ingot, therefore, double or triple remelting is usually used for the qualitative averaging of composition.

In the case of introducing the technology of doping zirconium in the process of magnesium thermal reduction [15], it is possible to reduce the number of remelts due to the fact that the resulting zirconium sponge will already have a chemical composition with a uniform distribution of alloying elements.

Based on the data on the temperature dependence of vapor pressure of niobium chlorides (Fig. 5) as well as other properties of niobium chloride compounds and the required level of alloy purity, niobium pentachloride is the most suitable product for the production of zirconium-niobium alloys.

However, mixtures of niobium chlorides and oxychlorides formed during the processing of titaniumcontaining materials cannot be used as an additional alloying component in the process of magnesium thermal production of niobium doped zirconium. Firstly, due to the difference in boiling and sublimation temperatures of oxytrichloride and niobium chlorides, as well as zirconium chlorides. Secondly, a significant amount of oxygen gets into the alloy through niobium oxychloride, which will definitely negatively affect the mechanical and corrosion properties of the alloys.

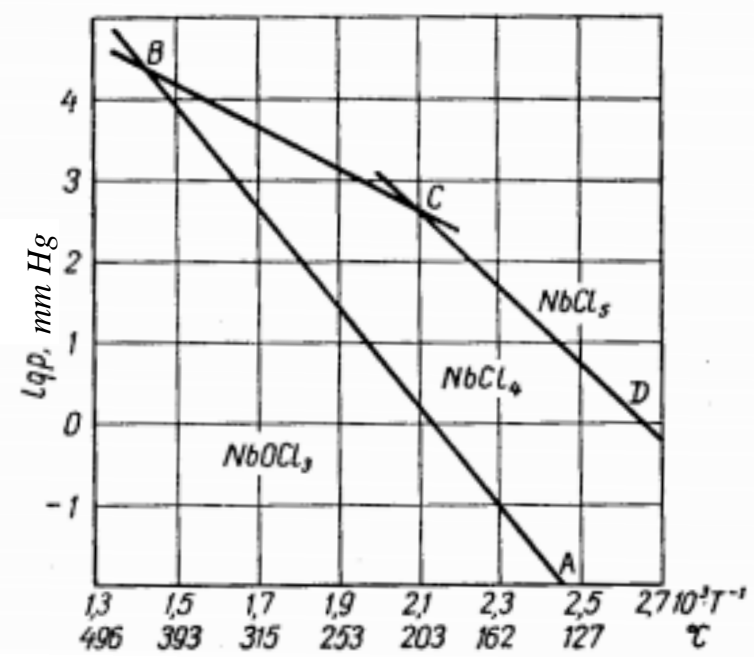

Fig. 5. Temperature dependence of vapor pressure of niobium chlorides

To eliminate these negative factors, a method and installation for the purification and chlorination of a mixture of chlorides were developed. According to the developed scheme, a mixture of niobium chlorides and oxychlorides of niobium is fed from a feed hopper to an experimental chlorination unit, which is chlorinated in the presence of carbon coke, evaporated and fed through a heated charcoal filter to a refrigerator, where it is condensed in the form of complete niobium chlorides. The main reactions of the process for producing niobium chlorides are to additional chlorination of the mixture according to the reactions (6)-(9):

$$
\begin{aligned}
& 4 \mathrm{NbOCl}_{3}+3 \mathrm{O}_{2}=2 \mathrm{Nb}_{2} \mathrm{O}_{5}+6 \mathrm{Cl}_{2} \\
& \mathrm{NbOCl}_{3}+\mathrm{Cl}_{2}+\mathrm{C}=\mathrm{NbCl}_{5}+\mathrm{CO} \uparrow \\
& 10 \mathrm{NbO}_{2}+5 \mathrm{Cl}_{2}=4 \mathrm{Nb}_{2} \mathrm{O}_{5}+2 \mathrm{NbCl}_{5} ; \\
& \mathrm{NbOCl}_{3}+\mathrm{Cl}_{2}+1 / 2 \mathrm{C}=\mathrm{NbCl}_{5}+0.5 \mathrm{CO}_{2} \uparrow(\mathrm{CO}) .
\end{aligned}
$$

Thus, the obtained purified niobium pentachloride can be used in the technology of complex alloying of sponge zirconium by the method of magnesium thermal reduction in order to obtain zirconium-niobium alloys for nuclear energy. In view of the fact that zirconium tetrachloride and niobium pentachloride are solids, both their combined purification and chlorination, as well as loading into a reduction reactor, are possible.

The sponge metal block with magnesium chloride residues and unreacted components obtained during the magnesiumthermal reduction process is subjected to vacuum thermal treatment, as a result of which a homogeneous compact metal block is formed with a uniform distribution of niobium in the structure. After machining the block with the removal of contaminated bottom and side parts, the metal must be sent for melting. From the point of view of obtaining highquality ingots, the most acceptable is the method of electron beam remelting (EBM). As a refining operation, the EBM has an advantage over the arc: the metal can withstand the necessary time in the molten state in the mold, which provides deep degassing and refining of the metal from volatile impurities having a higher vapor pressure than the molten metal. At high temperatures and deep vacuum, the refining process in electron beam furnaces proceeds with high speed and high efficiency. The high ductility of alloys remelted in an electron beam furnace allows all types of machining (forging, rolling, drawing, stamping, etc.) to be applied to them under conditions close to conventional metal forming methods [3].

\section{CONCLUSIONS}

1. A technological scheme has been developed for the processing of titanium-containing materials by chlorination with the removal of niobium oxychloride from the process by its additional chlorination in DSS, which allows the processing of raw materials with a high content of niobium.

2. A solution is proposed for the use of niobium derived from the chlorination process in the production of zirconium-niobium alloys.

3. A technology for the production of purified niobium pentachloride and a mixture of niobium and zirconium chlorides to implement the scheme of magnesium thermal reduction of sponge zirconium alloyed with niobium has been developed.

4. To obtain nuclear zirconium-niobium alloys, a method of electron beam remelting of alloyed sponge zirconium is proposed.

\section{REFERENCES}

1. V.V. Gavrilenko, V.V. Sakhonenok. Fundamentals of the geochemistry of rare lithophilic metals. Leningrad: Publishing House of the Leningrad University, 1986, 155 p. 
2. V.S. Chelnokov, I.V. Blinkov, V.N. Anikin, A.O. Volkhonsky. Refractory metals: application and properties of refractory metals: Textbook. M.: Publishing House MISiS, 2011, 114 p.

3. A.A. Maslov, R.V. Ostwald, V.V. Shagalov, E.S. Maslova, Yu.S. Gorenyuk. Chemical technology of niobium and tantalum. Tomsk: TPU Publishing House, 2010, $97 \mathrm{p}$.

4. A.N. Zelikman, B.G. Korshunov, A.V. Elyutin, A.M. Zakharov. Niobium and tantalum. M.: "Metallurgy", 1990, 296 p.

5. http://prometia.eu/wp-content/uploads /2014 /02/ NIOBIUM-TANTALUM-v02.pdf

6. Niobium-Market outlook to 2017 (12th ed.). London, United Kingdom, Roskill Information Services Ltd., 2013, 213 p.

7. G.A. Kolobov, A.V. Karpenko. Refining of light rare earth and radioactive metals // Problems of Atomic Science and Technology. 2016, N 1(101), p. 3-9.

8. G.O. Kolobov, T.M. Nesterenko, V.V. Pavlov, Yu.V. Mosseyko, A.V. Karpenko. Refining technology of refractory rare metals of group $V$ of the periodic table of the elements [Electronic resource]. Metallurgy. 2015 , v. 2, p. 33-38. Access mode: http://nbuv.gov.ua / UJRN/Metalurg_2015_2_8.
9. A.S. Muhamadeev. Electrolytic refining of niobium in chloride melts: The thesis for the degree of candidate of sciences. Yekaterinburg, 2004, 10 p.

10. Production of rare and rare-earth metals. Information and technical reference - ITR 24-2017.

11. Ya.G. Goroshenko. Chemistry of Niobium and Tantalum. Kiev: "Naukova dumka", 1965, 483 p.

12. V.I. Starshenko, B.N. Shkurin, S.A. Vaks, E.P. Medvedchikov, S.A. Kasparov. Development of a technology for processing various titanium-containing raw materials by chlorination in a molten salt // Collection of scientific papers. Zaporizhzhya: All-Union Research and Design Titanium Institute, 1990, 120 p.

13. V.M. Azhazha, P.N. Vyugov, S.D. Lavrinenko, et al. Zirconium and its alloys: production technology, applications. Kharkov: NSC KIPT, 1998, 98 p.

14. N.V. Baryshnikov, V.E. Heger, N.D. Denisova, et al. Metallurgy of zirconium and hafnium. M.: "Metallurgy", 1979, 208 p.

15. T.B. Yanko, A.V. Ovchinnikov. Development of the technology for complex alloying of rare metals with high melting point, titanium and zirconium // KhPI Herald, Collection of scientific works. Series: Mechanical and technological systems and complexes. 2015, N 22(1131), p. 155-159.

Статья поступила в редакичию 21.11.2019 г.

\title{
ПОПУТНОЕ ИЗВЛЕЧЕНИЕ НИОБИЯ ПРИ ПРОИЗВОДСТВЕ ТЕТРАХЛОРИДА ТИТАНА
}

\author{
Т.К. Сарсембеков, Т.Б. Янко, С.А. Сидоренко, Н.Н. Пилипенко
}

Разработаны основы технологии получения ниобия путем попутного извлечения в процессе производства тетрахлорида титана из титанового сырья. В работе представлены данные о количестве ниобия, содержащегося в исходном сырье для производства тетрахлорида титана, распределение ниобия в процессе переработки по продуктам и отходам производства. Рассмотрены формы фазовых превращений и переходы ниобия в процессе переработки. Предложены схемы переработки ниобийсодержащих хлоридных материалов и технологии их дальнейшего применения для получения сплавов для ядерной энергетики.

\section{ПОПУТНЕ ВИЛУЧЕННЯ НІОБІЮ ПРИ ВИРОБНИЦТВІ ТЕТРАХЛОРИДУ ТИТАНУ}

\section{Т.К. Сарсембеков, Т.Б. Янко, С.А. Сидоренко, М.М. Пилипенко}

Розроблено основи технології одержання ніобію шляхом попутного вилучення в процесі виробництва тетрахлориду титану з титанової сировини. У роботі наведено дані про кількість ніобію, що міститься у вихідній сировині для виробництва тетрахлориду титану, розподіл ніобію в процесі переробки за продуктами і відходами виробництва. Розглянуто форми фазових перетворень і переходи ніобію в процесі переробки. Запропоновано схеми переробки хлоридних матеріалів, що містять ніобій, і технології їх подальшого застосування для отримання сплавів для ядерної енергетики. 